\title{
Control of Browning in Lye-Peeled Taniers ${ }^{1}$
}

\author{
F. Sánchez-Nieva ${ }^{2}$
}

\begin{abstract}
Browning of lye-peeled tanier tubers could not be prevented satisfactorily by preheating them for 30 minutes in water at temperatures ranging from 140 to $170^{\circ} \mathrm{F}\left(60-77^{\circ} \mathrm{C}\right)$ before lye peeling at 200 to $210^{\circ} \mathrm{F}\left(93-99^{\circ} \mathrm{C}\right)$. Preheating increased peeling losses 50\%. Dipping the lye-peeled tubers in $1 \%$ citric acid solution reduced browning to the extent that trimming could be carried out without discoloration. Sulfitation to levels of $200 \mathrm{p} / \mathrm{m} \mathrm{SO}_{2}$ completely controlled the browning reaction. Sulfitation also improved the shelf life of frozen taniers stored at $-10^{\circ} \mathrm{F}\left(-23.3^{\circ} \mathrm{C}\right)$ for 210 days, preventing the development of off-flavors and changes in color. Sulfite uptake by taniers was found to be independent of the $\mathrm{pH}$ of the sulfiting solution, within the range of 5.3 to 3.3. Sulfite uptake increased in direct relationship to the concentration of sulfites in the sulfiting solution.
\end{abstract}

\section{INTRODUCTION}

Lye-peeled taniers emerge from the washer free of surface discoloration except for blemished areas due to suberized tissue, deep wounds, or rot. After a few minutes of air exposure, browning takes place, mostly around the apical and root buds. Discoloration starts as a brownish-red color which later turns black. Sometimes a greenish discoloration is also observed. Browning also occurs on the exposed cut surface after trimming, cutting, or slicing. When the inner tissue is exposed to the air, rapid discoloration also occurs around the fibrovascular bundles.

Browning in taniers follows the same pattern as that in many fruits and vegetables, suggesting that browning is due to an enzyme-catalyzed oxidative reaction $(2,4,10,11,14,22,24)$. This type of browning is caused by phenolases acting on phenolic substrates $(4,10)$, with the conversion of phenolic compounds to brown melanins. Injury of the tissue due to the action of heat or handling results in phenolase activation. The phenolase catalyzed browning results in extensive discoloration of the exposed surfaces of fruits and vegetables during the processing which adversely affects the appearance of the product.

There are several methods to control the enzymatic browning of

${ }^{1}$ Manuscript submitted to Editorial Board November 16, 1976.

${ }^{2}$ Chemical Engineer, Food Technology Laboratory, Agricultural Experiment Station, Mayagüez Campus, University of Puerto Rico, Río Piedras, P.R. The author wishes to express his gratitude to Mr. Iván Hernández, former Assistant Chemical Engineer, for his assistance in conducting some of the pilot plant experiments; to $\mathrm{Mr}$. J. M. Rivera, former Research Assistant, for the analyses of samples; and to Mrs. I. Caloni, Assistant Food Technologist, Food Technology Laboratory, for conducting the organoleptic tests. 
fruits and vegetables; the most common are heat inactivation of the enzyme system, lowering of $\mathrm{pH}$, and sulfitation (4, 10). This paper deals with the effect of these treatments on the control of the enzymatic browning of lye peeled taniers for freezing.

\section{MATERIALS AND METHODS}

Freshly harvested tubers of the Blanca cultivar, graded for size and with diameters from $1^{1 / 2}$ to 2 in $(3.8$ to $5.0 \mathrm{~cm}$ ), were used in the studies.

The tubers were soaked in water at room temperature $\left(80\right.$ to $85^{\circ} \mathrm{F}$; 26.7 to $29.4^{\circ} \mathrm{C}$ ) for $10 \mathrm{~min}$. After soaking, they were washed in a rotary rod-reel washer.

For lye peeling, two types of peelers were used; for small lots a batch peeler holding $200 \mathrm{lb}(91 \mathrm{~kg}$ ) of lye; for large lots a pilot plant scale peeler similar to the one described by Thurber and Bohne (23). The lyetreated tubers were washed in a rotary brush washer as described by Sánchez Nieva et al. (19).

Three treatments were tested to control the browning reaction: 1) Preheating the tubers in water: The graded and washed tubers were immersed in water heated to the desired temperature for the length of time required by the experiment. The preheated tubers were lye peeled as described above. 2) Acid treatment: From the washer, the lye-peeled tubers dropped into a tank containing a citric acid solution at room temperature. The strength of the citric acid solution varied from 1 to $5 \%$ by weight. 3) Sulfitation: The tubers were dipped in a $\mathrm{K}_{2} \mathrm{~S}_{2} \mathrm{O}_{5}$ solution at room temperature for different time spans. The concentration of the sulfiting solution varied as required by the experimental procedure. When $\mathrm{pH}$ adjustment was required, citric acid was added to adjust the $\mathrm{pH}$ to the desired value.

Any remaining peel, suberized tissue, and rotten and blemished areas were trimmed away. Except when otherwise indicated, trimming was done after the acid treatment, before sulfiting.

The tubers were packed in waxed cardboard containers which were overwrapped with vapor-proof moisture-proof, heat-sealable wrapping material, frozen in a plate freezer at $-40^{\circ} \mathrm{F}\left(-40^{\circ} \mathrm{C}\right)$, and stored at $-10^{\circ} \mathrm{F}\left(-23.3^{\circ} \mathrm{C}\right)$ until used.

For organoleptic tests, the frozen tubers were cooked without thawing. The content of one box (approximately $12 \mathrm{oz}(340 \mathrm{~g}$ ) was placed in a saucepan with two cups (.5 l) of boiling water and one teaspoon of table salt. The water was brought to boiling and the saucepan covered until the tubers were cooked, which required from 25 to $30 \mathrm{~min}$.

A ranking test was used for determining differences in flavor and appearance among samples from different treatments. For flavor comparisons several samples were presented to the tasters under red light. 
For appearance, the samples were ranked under daylight. The results of the test were statistically analyzed by the rank sum method described by Kramer (12).

Scalar tests were used for judging quality of individual samples and for rating quality attributes such as flavor, color, texture, off-flavor intensity, and overall sample quality. Samples were presented to tasters under daylight. A modified 6-point hedonic scale was used to rate the different quality attributes indicated.

For the determination of phenolase activity, a slice 1/8 in thick (3 $\mathrm{mm}$ ) was cut crosswise from a tuber. The slice was placed in an open petri dish and bathed with a $1 \%$ cathecol solution. Positive enzyme activity was indicated by the development of a brown color within 5 min of exposure to air (16).

Sulfite content in the treated tubers was determined by the Monnier Williams method (15) and is expressed as $\mathrm{p} / \mathrm{m} . \mathrm{SO}_{2}$.

\section{RESULTS AND DISCUSSION}

\section{NATURE OF THE BROWNING REACTION IN TANIERS}

When a thin slice cut from a fresh tuber is bathed with a $1 \%$ cathecol solution, rapid development of a brown color results in less than a minute, which on further standing in air turns black. When the slice is boiled in water for over $5 \mathrm{~min}$, no color develops on the addition of cathecol even after prolonged exposure to air. This indicates the presence of phenolase, which in the presence of oxygen reacts with cathecol to give a yellowish brown pigment within $5 \mathrm{~min}$, and which on further exposure to air turns black (11).

Mapson and Tomalin (13), working with enzyme preparations from potato tissue, determined the minimum heat treatment necessary to activate the phenolosase. Phenolase inactivates when heated to $80^{\circ} \mathrm{C}$ $\left(176^{\circ} \mathrm{F}\right)$ for $3 \mathrm{~min}$, at $90^{\circ} \mathrm{C}\left(194^{\circ} \mathrm{F}\right)$ for $1^{1 / 2} \mathrm{~min}$ and at $100^{\circ} \mathrm{C}\left(212^{\circ} \mathrm{F}\right)$ for $0.75 \mathrm{~min}$. When $1 / 8$ in $(3 \mathrm{~mm})$ thick slices were heated in water at $195^{\circ} \mathrm{F}\left(90.5^{\circ} \mathrm{C}\right)$ for various lengths of time, a negative reaction to cathecol resulted when heating for $5 \mathrm{~min}$ or longer. Since a $1 / 8$ in (3 $\mathrm{mm}$ ) thick slice takes time to be heated throughout to the inactivating temperature, it is to be expected that a longer time will be required for complete inactivation of the enzyme than when an enzyme isolate is heated.

\section{HEAT TREATMENTS TO CONTROL BROWNING}

Due to a very low heat transfer it is impossible to inactivate the enzyme system in the tubers without cooking for a relatively long time. Cooking results in undesirable changes in texture and flavor 
which render the tubers unsuitable for processing and freezing. However, since the peeled tubers develop browning mainly in the exposed surface it may be possible to inactivate by heating the phenolase in the upper layers to a depth that will prevent browning on exposure to air during handling and trimming.

Scott et al. (20) controlled browning in sweet potatoes by preheating the roots so that on lye peeling a temperature above $195^{\circ} \mathrm{F}\left(90.5^{\circ} \mathrm{C}\right)$ would be attained to inactivate the cathecol oxidase. He obtained results by preheating the sweet potatoes to $125^{\circ} \mathrm{F}\left(51.5^{\circ} \mathrm{C}\right)$ for $30 \mathrm{~min}$. This treatment reduced trimming, although peeling losses were higher. González et al. (7) working with two varieties of sweet potato grown in Puerto Rico found that the temperature to which the tuber had to be heated to inactivate the phenolase was affected by varietal characteristics. The Cobre cultivar achieved enzyme inactivation when preheated $30 \mathrm{~min}$ at $135^{\circ} \mathrm{F}\left(57^{\circ} \mathrm{C}\right)$ and peeled in $10 \%$ lye at $210^{\circ} \mathrm{F}\left(99^{\circ} \mathrm{C}\right)$. The U.P.R. 3 variety had to be preheated $30 \mathrm{~min}$ at $165^{\circ} \mathrm{F}\left(74^{\circ} \mathrm{C}\right)$ to obtain a similar level of inactivation.

Preheating taniers for $30 \mathrm{~min}$ in water at 150,160 and $170^{\circ} \mathrm{F}(66,71$, $\left.77^{\circ} \mathrm{C}\right)$ and lye peeled at $200^{\circ} \mathrm{F}\left(93^{\circ} \mathrm{C}\right)$ did not control browning. Browning was slower in the samples heated to $170^{\circ} \mathrm{F}\left(77^{\circ} \mathrm{C}\right)$.

Fig. 1 shows the effect on browning of preheating the tubers for 30 min in water at 140,150 and $160^{\circ} \mathrm{F}\left(60,66,71^{\circ} \mathrm{C}\right)$, when lye peeling in $15 \%$ lye at $210^{\circ} \mathrm{F}\left(99^{\circ} \mathrm{C}\right)$. The control sample suffered intensive browning around the apical and root buds. Browning was more intense at $140^{\circ} \mathrm{F}\left(60^{\circ} \mathrm{C}\right)$, probably due to the activation of phenolase by heat (20). In the sample heated to $150^{\circ} \mathrm{F}\left(66^{\circ} \mathrm{C}\right)$ the extent of browning was less. The control samples, as well as those heated at 140 to $150^{\circ} \mathrm{F}(60$, $66^{\circ} \mathrm{C}$ ), gave positive reactions to cathecol. The sample heated at $160^{\circ} \mathrm{F}$ $\left(71^{\circ} \mathrm{C}\right)$ gave a positive but faint reaction with cathecol, indicating partial inactivation of the phenolase. There was less browning in the other samples.

Preheating to higher temperatures to inactivate the phenolases completely was excluded for practical reasons. Preheating increased peeling losses considerably (19). In the samples shown in figure 1 , the loss in weight for the control sample during peeling and washing averaged $21.4 \%$, while the corresponding losses in weight in the preheated samples ranged from 20 to $36 \%$. No direct relationship was observed between preheating temperature and weight loss within the range of temperature tested.

Furthermore, disregarding browning, the samples heated at $160^{\circ} \mathrm{F}$ $\left(71^{\circ} \mathrm{C}\right)$ had a poor appearance. The surface was roughened by the brushes of the washer on the softened tissue. A gray tinge masked the characteristic attractive white appearance of the flesh of the Blanca cultivar. 
Because none of the preheating treatments tested controlled browning effectively and peeling losses increased in about $50 \%$ of the cases, preheating is not recommended to control browning in taniers in commerical processing operations.

\section{ACID DIP AND SULFITATION}

A method widely used to control the browning due to enzyme activity in fruits and vegetables involves the use of acids and sulfitation. The

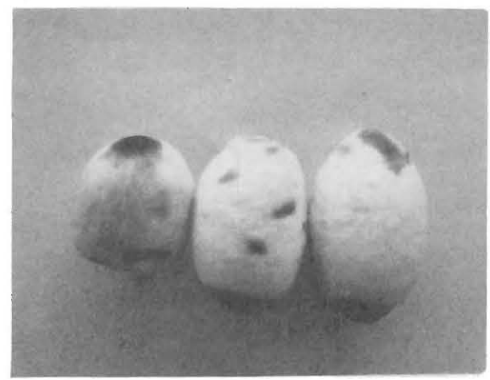

CONTROL

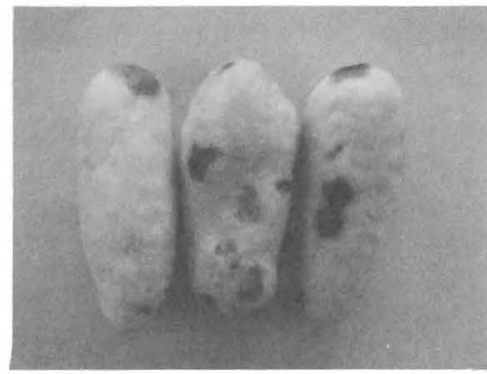

$150^{\circ} \mathrm{F} \quad 66^{\circ} \mathrm{C}$

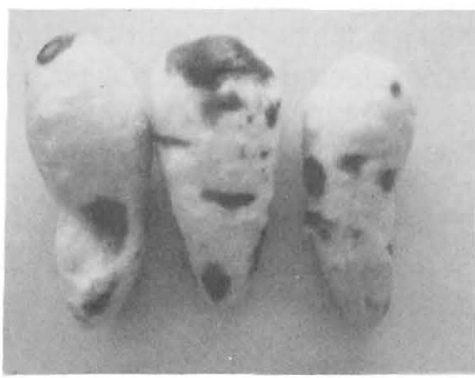

$140^{\circ} \mathrm{F} \quad 60^{\circ} \mathrm{C}$

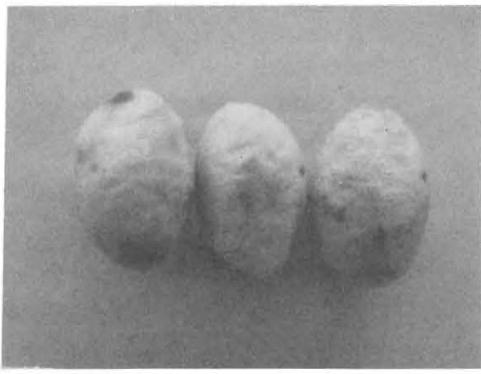

$160^{\circ} \mathrm{F} 71^{\circ} \mathrm{C}$

FiG. 1.-Effect on browning of preheating to different temperatures for $30 \mathrm{~min}$ before lye peeling. Tubers in $15 \%$ lye at $210^{\circ} \mathrm{F}\left(99^{\circ} \mathrm{C}\right)$.

optimum $\mathrm{pH}$ for phenolase activity lies between 6 and 7 . Lowering the $\mathrm{pH}$ decreases enzyme activity with almost no activity below pH 3.0 (4, 10). The browning of lye-peeled peaches has been controlled by rinsing the peaches in acid (3).

Sulfur dioxide and the sulfites are powerful inhibitors of phenolase. The use of sulfites to control the browning reaction of several products is widely practiced $(6,8,9,18,21,22)$.

Table 1 gives the results of a series of experiments in which several 
acid and sulfite treatments were tested for their effectiveness in the control of browning in lye-peeled taniers. A rinse in a 5\% citric acid solution alone or in combination with sulfitation controlled browning. Immersion for $5 \mathrm{~min}$ in a $5 \%$ citric acid solution controlled browning to the extent that trimming could be carried out without any discoloration taking place before sulfitation.

Frozen samples from the different treatments listed in table 1 were ranked for flavor and appearance. The results of the test indicate that tasters could not detect a difference in flavor among the samples. In regard to appearance, the control sample (table 1) was rejected as inferior while the acid-treated sulfited samples (lots 3 and 4, table 1) were selected as superior $(\mathrm{P}>.05)$.

TABLE 1. - Effect of acid and sulfite treatments on the discoloration of lye-peeled tubers

\begin{tabular}{|c|c|c|c|}
\hline \multirow{2}{*}{$\begin{array}{l}\text { Lot } \\
\text { No. }\end{array}$} & \multirow{2}{*}{ Treatment } & \multicolumn{2}{|c|}{ Visual observation of extent of browning } \\
\hline & & Immediately after treatment & On frozen samples \\
\hline 1 & $\begin{array}{l}\text { Control, discharged from } \\
\text { washer into water, } \\
\text { trimmed to remove } \\
\text { blemishes }\end{array}$ & $\begin{array}{l}\text { Extensive and strong } \\
\text { discoloration }\end{array}$ & $\begin{array}{l}\text { Extensive and strong dis- } \\
\text { coloration }\end{array}$ \\
\hline 2 & $\begin{array}{l}\text { 5-min immersion in } 5 \% \\
\text { citric acid solution, fol- } \\
\text { lowed by trimming }\end{array}$ & $\begin{array}{l}\text { No discoloration even } \\
\text { after trimming }\end{array}$ & $\begin{array}{l}\text { No evidence of discolora- } \\
\text { tion }\end{array}$ \\
\hline 3 & $\begin{array}{l}\text { 5-min immersion in } 5 \% \\
\text { citric acid solution; } 5 \text { - } \\
\text { min immersion in } 1 \% \\
\mathrm{~K}_{2} \mathrm{~S}_{2} \mathrm{O}_{5} \text { at pH } 3.0 \\
\text { trimmed }\end{array}$ & $\begin{array}{l}\text { No discoloration after } \\
\text { trimming }\end{array}$ & $\begin{array}{l}\text { No evidence of discolora- } \\
\text { tion }\end{array}$ \\
\hline 4 & $\begin{array}{l}\text { 5-min immersion in } 5 \% \\
\text { citric acid solution, } \\
\text { trimmed, } 5 \text {-min immer- } \\
\text { sion in } 1 \% \mathrm{~K}_{2} \mathrm{~S}_{2} \mathrm{O}_{5} \text { solu- } \\
\text { tion at } \mathrm{pH} 3.0\end{array}$ & $\begin{array}{l}\text { No discoloration before } \\
\text { or after trimming; } \\
\text { no discoloration after } \\
\text { sulfiting }\end{array}$ & $\begin{array}{l}\text { No evidence of discolora- } \\
\text { tion }\end{array}$ \\
\hline
\end{tabular}

According to these results, a combination of acid and sulfiting produces frozen taniers of better quality. Although tasters could not detect a significant difference in flavor among the samples listed in table 1, some tasters indicated that the acid-treated and sulfited samples had a slightly objectionable flavor. Since previous experience had shown that at the level of sulfitation used no off-flavors are usually detected, it was suspected that the objectionable flavor found in this sample was due to the effect of the acid treatment.

Table 2 presents the results of organoleptic tests conducted to determine the effect of acid concentration and length of treatment on the flavor and appearance of lye-peeled acid-treated tubers. When acid 
concentrations of 1 and $3 \%$ were used, an increase in the length of dip from 1 to $5 \mathrm{~min}$ had no effect or appearance. When treated in a $5 \%$ acid solution, the tubers dipped for 5 min were rejected as inferior in flavor at the $5 \%$ probability level.

When the tubers treated in the three acid concentrations for equal length of time were compared the sample treated in the $5 \%$ citric acid solution was found inferior in flavor to the other two.For a dipping time of 1 and $3 \mathrm{~min}$ no significant difference was found between the samples treated in 1 and $3 \%$ citric acid; however, at a $5 \mathrm{~min}$ dip, the sample treated in $1 \%$ citric acid was found to be superior in flavor.

These results confirm that the flavor of the taniers is affected by acid treatment. To reduce the possibility of changes in flavor, a short dip in a low acid concentration should be used.

TABLE 2,-Results of organoleptic rating of different quality attributes

\begin{tabular}{|c|c|c|c|c|}
\hline \multirow{2}{*}{ Treatments judged } & \multicolumn{2}{|c|}{ Scores $^{1}$} & \multirow{2}{*}{$\begin{array}{l}\text { Intensity of } \\
\text { off flavors }\end{array}$} & \multirow{2}{*}{$\begin{array}{l}\text { Overall } \\
\text { sample } \\
\text { quality }\end{array}$} \\
\hline & Appearance & Flavor & & \\
\hline Acid treated & 0.88 & 2.4 & 3.68 & 1.7 \\
\hline Sulfited 3 minutes & 3.2 & 2.9 & 4.0 & 2.9 \\
\hline Sulfited 5 minutes & 3.1 & 3.3 & 4.7 & 3.4 \\
\hline Sulfited 7 minutes & 3.3 & 3.3 & 4.8 & 3.6 \\
\hline
\end{tabular}

' Scoring system: Appearance: Very attractive - 5; Poor - 0 .

Flavor: Very Good - 5; very disagreeable -0 .

Off flavor intensity: No off flavors -5 ; very strong off flavors -0 .

Sample quality: Very good -5 ; very poor -0 .

When lye-peeled tubers were treated with a $1 \%$ acid solution browning was retarded to make possible trimming of the roots without coloration. It was observed that at this low acid concentration some browning took place around the apical and root buds as evidenced by the development of a pale yellowish coloration. This discoloration disappeared on sulfitation.

\section{SULFITATION}

Sulfites, including the bisulfites and metabisulfites of $\mathrm{Na}$ and $\mathrm{K}$, are widely used to control browning in food products. The use of any of these compounds as sulfiting agents is a matter of choice, since, within the physiological $\mathrm{pH}$ range, when dissolved in water, all exist in the same state as a mixture of sulfite and bisulfite ions (5). In this study, potassium metabisulfite was chosen as the sulfiting agent, mainly because of the stability of its solutions at room temperature.

Figure 2 shows the effect of concentration and $\mathrm{pH}^{\mathrm{H}}$ on $\mathrm{SO}_{2}$ uptake by lye-peeled taniers. $\mathrm{SO}_{2}$ uptake was more influenced by sulfite concentra- 


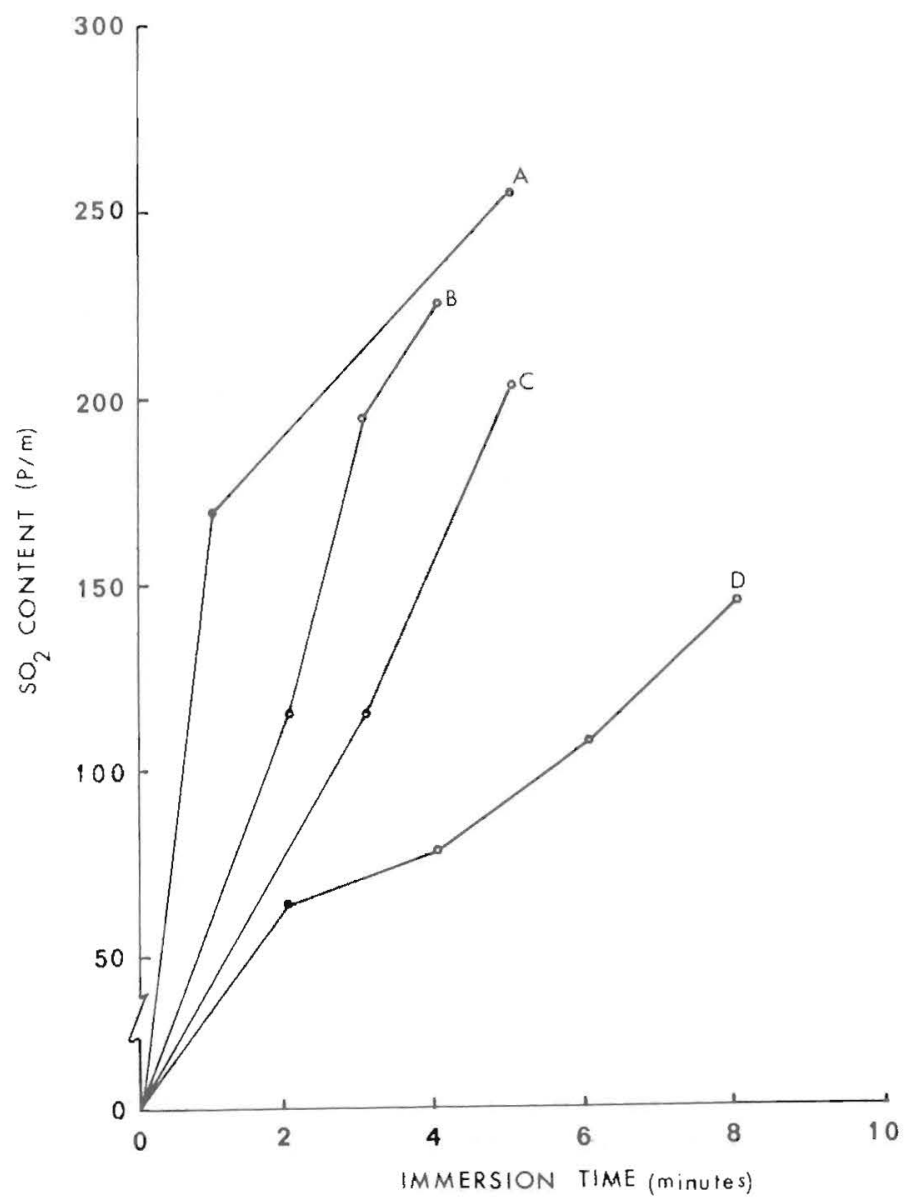

FIG. 2.-Effect of sulfite concentration, $\mathrm{pH}$ of sulfiting solution, and time of immersion on the $\mathrm{SO}_{2}$ uptake by lye-peeled tubers. Sulfite concentration as $\mathrm{SO}_{2}$ in $\mathrm{p} / \mathrm{m}$ and $\mathrm{pH}$ of sulfiting solutions: Curve $\mathrm{A}-8060$, 5.25; Curve $\mathrm{B}-7739,3.30$; Curve $\mathrm{C}-$ 4744, 3.30; Curve D-2700, 3.30.

tion than by $\mathrm{pH}$. Changing the $\mathrm{pH}$ of the sulfiting solution from 5.2 to 3.3 had little effect on $\mathrm{SO}_{2}$ uptake. On the other hand, increasing the concentration of $\mathrm{SO}_{2}$ from 2700 to $8060 \mathrm{p} / \mathrm{m}$ markedly increased $\mathrm{SO}_{2}$ uptake.

In prepeeled potatoes, Amla and Francis (1), Ross and Treadway (17) and Francis and Amla (16) found the $\mathrm{SO}_{2}$ uptake to be directly related to the $\mathrm{pH}$ of the sulfiting solution. Similar relationships were observed in sulfiting corn by Hayes et al. (8), in apricots by Stafford and Boilin (21), and in green plantains by Sánchez-Nieva et al. (18). The data 
from these studies, however, indicate that in taniers, sulfite uptake seems to be independent of $\mathrm{pH}$ within the range tested. In another series of experiments in which lye-peeled taniers were sulfited in $\mathrm{Na}_{2} \mathrm{SO}_{3}$ solution at $\mathrm{pH} 8.85$ and in $\mathrm{K}_{2} \mathrm{~S}_{2} \mathrm{O}_{5}$ solutions at $\mathrm{pH} 3.3$ and 5.25 at approximately the same concentration of $\mathrm{SO}_{2}, \mathrm{SO}_{2}$ uptake was found also to be independent of $\mathrm{pH}$.

The curves on figure 2 show that sulfite uptake by the tubers increased rapidly during the first min of immersion. During the first 3 min of treatment, sulfite uptake increased to $45-60 \%$ of the final uptake from an immersion time ranging from 5 to $8 \mathrm{~min}$.

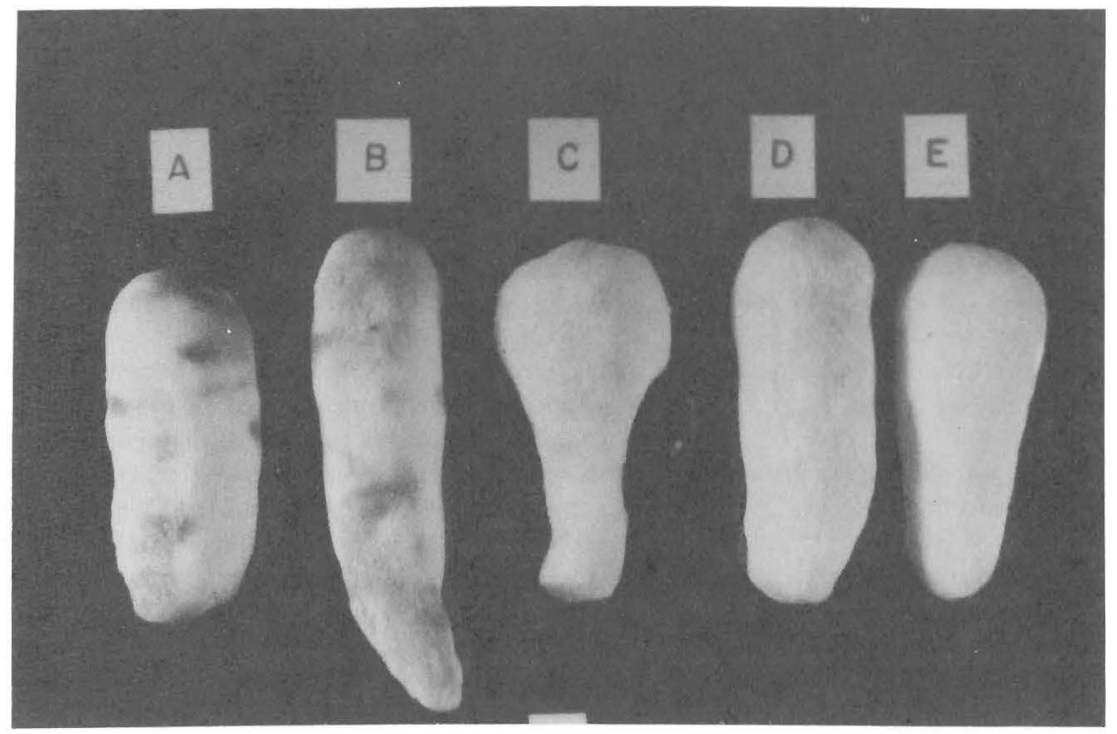

FIG. 3.-Effect of sulfiting on the appearance of frozen taniers A-Control; BDipped in $1 \%$ citric acid; $\mathrm{C}-$ Sulfited, $123 \mathrm{p} / \mathrm{m} \mathrm{SO}_{2} ; \mathrm{D}$ and $\mathrm{E}-203 \mathrm{p} / \mathrm{m} \mathrm{SO}_{2}$.

Figure 3 shows the effect of sulfitation to a level of 123 to $223 \mathrm{p} / \mathrm{m}$ $\mathrm{SO}_{2}$ on the appearance of frozen taniers of the Blanca cultivar. An untreated control sample and an acid dipped (1\% citric acid) sample are included in the pictures for comparison. The sulfited tubers are completely free from coloration due to browning while the control and the acid-treated samples clearly show the typical coloration of enzymatic browning.

To determine the effect of sulfitation on flavor, the samples shown in figure 3 were ranked after one month of storage at $-10^{\circ} \mathrm{F}\left(-23.3^{\circ} \mathrm{C}\right)$. The test showed that tasters could not detect any difference in flavor between sulfited samples and controls. 
When the ranking test was repeated after a storage period of 210 days at $-10^{\circ} \mathrm{F}\left(-23.3^{\circ} \mathrm{C}\right)$ in which the acid-treated and the sulfited samples were compared for flavor and appearance, the acid-treated sample was rejected as inferior in flavor and appearance $(\mathrm{P}>.01)$ while no difference in flavor or appearance was found among the sulfited samples.

Table 3 gives the results obtained when same samples were submitted separately to organoleptic evaluation using a 6-point scale to rate the different quality attributes. The data show that the acid-treated samples scored lower in all quality attributes. The two samples sulfited to a level of $200 \mathrm{p} / \mathrm{m}$ received similar ratings for all quality attributes. It is evident from these results that sulfitation improved the quality and

TABLE 3. - Results of organoleptic comparisons by ranking of acid treated and sulfited tubers

\begin{tabular}{|c|c|}
\hline Treatments compared & Results \\
\hline $\begin{array}{l}\text { Dipped in } 1 \% \text { citric acid solution } \\
\text { for } 1,3 \text {, and } 5 \text { min }\end{array}$ & $\begin{array}{l}\text { No significant difference among treatments in } \\
\text { flavor or appearance. }\end{array}$ \\
\hline $\begin{array}{l}\text { Dipped in } 3 \% \text { citric acid solution } \\
\text { for } 1,3 \text {, and } 5 \text { min }\end{array}$ & $\begin{array}{l}\text { No significant difference among treatments in } \\
\text { flavor or appearance. }\end{array}$ \\
\hline $\begin{array}{l}\text { Dipped in } 5 \% \text { citric acid solution } \\
\text { for } 1,3 \text {, and } 5 \text { min }\end{array}$ & $\begin{array}{l}\text { No significant difference among treatments in } \\
\text { appearance. Sample treated in the acid solu- } \\
\text { tion for } 5 \text { minutes inferior in flavor }(5 \% \mathrm{P}) \text {. }\end{array}$ \\
\hline $\begin{array}{l}\text { Dipped } 1 \text { min in } 1,3 \text {, and } 5 \% \text { citric } \\
\text { acid solution }\end{array}$ & $\begin{array}{l}\text { No significant difference among treatments in } \\
\text { appearance. Sample treated in } 5 \% \text { citric acid } \\
\text { solution found inferior in flavor at } 5 \% \mathrm{P} \text {. }\end{array}$ \\
\hline $\begin{array}{l}\text { Dipped } 3 \text { min in } 1,3 \text {, and } 5 \% \text { citric } \\
\text { acid solution }\end{array}$ & $\begin{array}{l}\text { No significant difference among treatments in } \\
\text { flavor or appearance. }\end{array}$ \\
\hline $\begin{array}{l}\text { Dipped } 5 \text { min in } 1,3 \text {, and } 5 \% \text { citric } \\
\text { acid solution }\end{array}$ & $\begin{array}{l}\text { Sample treated with } 1 \% \text { citric acid found supe- } \\
\text { rior in flavor at } 5 \% \mathrm{P} \text {. Sample treated in } 5 \% \\
\text { citric acid rejected as inferior in flavor (1\% P), } \\
\text { but superior in appearance ( } 5 \% \mathrm{P}) \text {. }\end{array}$ \\
\hline
\end{tabular}

shelf life of frozen taniers by effectively controlling browning and by preventing the development of off-flavor during storage.

Frozen taniers are usually boiled in water for about 20 to $30 \mathrm{~min}$ before serving. Taniers sulfited to levels of $236 \mathrm{p} / \mathrm{m}$ were found to lose on cooking about $85 \%$ of the original $\mathrm{SO}_{2}$ content. The level of $\mathrm{SO}_{2}$ remaining in the cooked tuber is too low to be detected as off-flavor by the consumer.

\section{RESUMEN}

Se ensayaron distintos métodos para controlar la reacción de pardeamiento en yautías tratadas con soda caliente $\left(200\right.$ y $210^{\circ} \mathrm{F} ; 93$ y $\left.99^{\circ} \mathrm{C}\right)$ para pelarlas. Un precalentamiento por 30 minutos en agua a temperaturas de $140,150,160$ y $170^{\circ} \mathrm{F}$. (60, $66,71,77^{\circ} \mathrm{C}$.) antes del tratamiento con soda no evitó el pardeamiento de los tubérculos al exponerlos al aire. El precalentamiento aumentó las pérdidas al pelar con soda en alrededor de un 50 por 100 .

La reacción de pardeamiento pudo controlarse satisfactoriamente sumergiendo las 
yautías, yá peladas, en una solución de ácido cítrico al $1 \%$ por varios minutos, y luego sulfitando hasta un nivel de $200 \mathrm{ppm}$ de $\mathrm{SO}_{2}$. El tratamiento con el ácido cítrico redujo la acción enzimática y el pardeamiento lo suficiente para poder limpiar los tubérculos sin cambios apreciables en el color. La sulfitación evitó totalmente la reacción de pardeamiento. La sulfitación también mejoró la calidad de la yautía congelada, evitando el desarrollo de sabores extraños y cambios en el color mientras estaba almacenada a $-10^{\circ} \mathrm{F} .\left(-23.3^{\circ}\right.$ C. $)$ durante más de 200 días.

El estudio de los procedimientos seguidos en la sulfitación demostró que la absorción de sulfitos en la yautía parece ocurrir independientemente del $\mathrm{pH}$ de la solución sulfitante. El nivel de $\mathrm{SO}_{2}$ en los tubérculos sulfitados aumenta en proporción a la concentración de la solución sulfitante.

Durante el proceso de cocción de los tubérculos congelados se pierde alrededor de un 85 por 100 del contenido original de $\mathrm{SO}_{2}$ quedando un nivel residual de $\mathrm{SO}_{2}$ que normalmente no puede ser detectado por el sabor.

\section{LITERATURE CITED}

1. Amla, B. L., and Francis, F. J., Effect of $\mathrm{pH}$ of dipping solutions on the quality of pre-peeled potatoes, Am. Potato J. 38: 121-30, 1961.

2. Arthur, J. C., and McLemore, T. A., Properties of polyphenolases causing discoloration of sweet potatoes during processing, Agric. Food Chem. 4(6): 553-5, 1956.

3. Cruess, W. V., Quin, P. J., and Mrak, E. M., Observations on the browning of canning peaches, Fruit Prod. J. 12: 38-40, 1932.

4. Eskin, N. A. M., Henderson, H. M., and Townsend, R. J., Biochemistry of Foods, Academic Press, New York, 69-83, 1971.

5. Expert Panel of Food Safety and Nutrition of I. F. T., Sulfites as food additives, Food Technol. 29(10): 117-20, 1975.

6. Francis, F. J., and Amla, B. L., Effect of residual $\mathrm{SO}_{2}$ on the quality of pre-peeled potatoes, Am. Potato J. 38: 89-94, 1961.

7. González, M. A., Benero, J., and Sánchez-Nieva, F., Canning characteristics of the Cobre variety sweet potato. J. Agric., Univ. P.R. 45(2): 106-11, 1961.

Hayes, R. E., Nelson, A. I., and Steinberg, M. P., Considerations in sulfiting sweet corn with an aqueous salt solution prior to dehydration, Food Technol. 10: 18-22, Jan. 1956.

9. Joslyn, M. A., and Mrak, E. M., Investigations on the use of sulfurous acid and sulfites in the preparation of fresh and frozen fruits for bakers' use, Fruit Prod. J. 12: $135-40,1933$.

10. Joslyn, M. A., and Ponting, J. D., Enzyme catalyzed oxidative browning of fruit products, Adv. Food Res. 3: 1-44, 1951.

11. Kahn, V., Polyphenol oxidase activity and browning of three avocado varieties, J. Sci. Food Agric. 26: 1319-24, 1975.

12. Kramer, A., A rapid method for determining significance of differences from rank sums, Food Technol. 14(11): 576-81, 1960.

13. Mapson, L. W., and Tomalin, A. W., Preservation of peeled potatoes. III. The inactivation of phenolase by heat, J. Sci. Food Agric. 12: 54-8, 1961.

14. Martin, F. W., and Ruberté, R., The polyphenol of Dioscorea alata (yam) tubers associated with oxidative browning, J. Agric. Food Chem. 24(1): 67-70, 1976.

15. Official Methods of Analysis of the Association of Official Agricultural Chemists, 9th ed, Washington, D.C., 1960.

16. Ponting, J. D., Cathecol test for frozen fruits, Quick Frozen Foods 7(5): 31, 1944.

17. Ross, L. R., and Treadway, R. H., Factors affecting $\mathrm{SO}_{2}$ uptake in sulfited prepeeled potatoes, Am. Potato J. 38: 9-13, 1961.

18. Sánchez-Nieva, F., Bueso, C. E., and Hernández, I., Studies on the freezing of green plantains. II. Sulfitation to control browning, J. Agric. Univ. P.R. 59(2): 92-106, 1975.

19. — and Hernández, I., Lye peeling of taniers (Xanthosoma spp.), J. Agric. Univ. 
P.R. 61(3): 345-53, 1977.

20. Scott, L. E., Walls, E. P., and Hunter, H. A., How to prevent discoloration of sweet potatoes, Food Packer 26(8): 48-50, 66, 1945.

21. Stafford, A. E., Bolin, H. R., and Mackey, B. E., Absorption of aqueous bisulfite by apricots, J. Food Sci. 37: 941-3, 1972.

22. Talburt, W. F., and Smith, D., Potato Processing, The Avi Publishing Co., Westport, Conn., 1967.

23. Thurber, F. H., and Bohne, P. W., Rotary machine solves lye peeler problems, Food Ind. 18: 10-11, 148-50, 1945.

24. Woodroof, J. G., DuPree, W. E., and Cecil, S. R., Canning sweet potatoes, Georgia Agric. Exp. Stn. Bul. N. S. 12: 46-8, 1955. 